[Dalli, C., \& Te One, S. (2003). Early Childhood Education in 2002: Pathways to the Future. New Zealand Annual Review of Education, 12, 177202]

\section{Early Childhood Education in 2002: Pathways to the Future}

\section{CARMEN DALLI AND SARAH TE ONE}

\section{Abstract:}

In September 2002, the New Zealand Government released Pathways to the Future: Ngā Huarahi Arataki, its policy statement in support of the ten-year strategic plan for the early childhood education sector. The document identifies three core goals as a focus for government action: increasing participation in quality early childhood education (ECE) services; improving quality of ECE services; and promoting collaborative relationships. This article positions Pathways to the Future within the broader context of recent early childhood policy and current discourse about children and children's rights. It discusses the policy strategies implemented during 2002 in support of the three core goals of the strategic plan, and reviews gains and remaining challenges.

$\mathrm{T}$

he big event for the early childhood sector in 2002 was undoubtedly the release in September of the government's policy statement in support of the ten-year strategic plan for the sector: Pathways to the Future: NgāHuarahi Arataki (Ministry of Education, 2002).

This article positions the event within the broader context of early childhood policy over recent years, and current discourse about children and children's rights. We argue that Pathways to the Future is the culmination of activism by the sector to reclaim its policy voice and win back government support for a long-term coherent policy for early childhood services. This type of support was achieved briefly at the end of the eighties with the Before Five policies (Lange, 1988), but dissipated rapidly in the nineties. The activism of the sector during the 1990s ebbed and flowed with the changing tides of government's variable levels of commitment to the sector, and with the sector's own ability to come together and speak with one voice at the policy table. The year
2002 was a watershed in many ways. We review the gains made and outline remaining challenges.

\section{An Overview Of Recent Early Childhood Policy}

Government's policy for early childhood services began in 1948 when it decided to fully fund kindergartens, and kindergarten teachers became state employees. Other forms of early childhood provision grew largely through community action in response to community need. These services had to compete for funding from government and from other sources with parental fees making up the shortfall (May, 2001).

By the end of the 1980s the early childhood sector was a diverse and uncoordinated one with around 2700 early childhood centres run by at least twenty different types of services. Education to be More (Meade, 1988), which reported on a review of early childhood services carried out in the late 1980s, outlined the issues faced by the sector. These included issues of equity of access, funding inequities, ensuring quality provision, addressing the low status of early childhood work; and issues of provision for Māori children and whanau, the tangata whenua of Aotearoa New Zealand. The Meade Report, as the review became known, described access to early childhood services as problematic, both in terms of affordability of services, and in terms of availability of places for children of diverse ages, as well as by locality and ethnic background. For Māori children and whanau the issue was also one of ensuring structures existed that supported Māori control over the development of ngā kohanga reo (Meade, 1988, p. 39). In the late eighties, the number of kohanga reo was rapidly increasing. For Pacific Nations children, under-representation in existing services was an issue alongside the resourcing of Pacific Island Language Groups to meet training and building specification standards. The Meade Report recognised that funding inequities were largely historical in origin with "preschool" services, such as kindergarten and playcentre, generally receiving higher funding than "childcare" or "daycare" services. Childcare services received only minimal government support and were regulated through the Child Care Centres Regulations gazetted in 1960. At the end of the eighties, diversity reigned on all fronts: there was diversity of programmes, diversity of staff training and qualifications, and diversity of history and philosophy. Child-staff ratios also varied greatly across services with the regulations specifying only minimal requirements. Early childhood work was among the most lowly paid in the education sector and the attendant low status and low prestige were 
"core elements of the EC workers' professional reality" (Dalli, 1990, p. 68). This made well-qualified staff difficult to attract and retain and added to the problem of ensuring quality of provision in this hugely diverse sector. The as-yet-undefined early childhood curriculum was also seen as compounding the issue of ensuring quality in provision.

Government's response to the Meade Report was the policy document Before Five (Lange, 1988). In a comprehensive attempt to address the issues raised in the Meade Report, Government announced a four-year-staged plan of higher funding intended to put all early childhood services on the same funding footing by the end of the period. Additionally, new quality guidelines were released that, when met, would ensure higher funding for early childhood services. These guidelines included improved staff:child ratios, and higher training requirements for early childhood work. Such government action to rationalise the provision of early childhood services was unprecedented in the sector. Remarkably, the policies were made at a time when there was pressure from the Treasury and other interest groups within government to cut expenditure and decentralise state responsibility (Meade, 1990). In many ways, early childhood policy was bucking the trend, and analyses of early childhood policy of that time have commented on how this outcome was impacted by activist politics, including that of unions, an emerging unity among the diverse early childhood services, and the importance of people in key positions (Meade, 1990).

The Before Five policies engendered much optimism and enthusiasm in the early childhood sector (Burns, 1989; Dalli, 1990). Sadly, however, these were to be short-lived. Barely a year into their operation, the Before Five funding and quality policies were dismantled by the "New Right" National government elected in November 1990 (Dalli, 1993; Meade \& Dalli, 1991).

The post-Before Five decade was a time of retrenchment when government discourse included a focus on family responsibility and freedom from state dependence. In early childhood policy this translated into a non-interventionist stance and a discourse of "purchasing services" from early childhood providers, and ensuring accountability for public monies. Increasing access was another element of government discourse, but this was to be achieved through market forces, not government intervention. Many argued that increased access was achieved at the expense of quality (Early Childhood Education Project, 1996; May, 2001; Meade, 2000; Mitchell, 1996).
In the 1990s, the stance of the government towards early childhood policy was very much in line with the general "rolling back of the state" phenomenon that marked the three terms of National (or Nationaldominated) government (May, 2001; Mitchell, 1995; Wells, 1998). A "subsidy" model of state support, versus universal funding, was followed and applied to all types of early childhood services, whether community-based or privately-run. Even kindergartens, once the flagship of the early childhood sector (Davison, 1997) lost their privileged position. Through the operation of the early childhood bulk grant, they came under increasing pressure to operate like private businesses, and in 1997 they were expelled from the State Sector Act a position they only regained in 2000 after a change of government.

Within this non-interventionist stance by government, and at a time when the restructuring of educational administration had left early childhood without its own policy voice in the Ministry of Education (May, 1991), the early childhood sector was very much in a state of policy disarray, and without a clear forum through which to position its policy agenda. One of us has argued elsewhere (Dalli, 2002), that it remained for the sector to take the initiative and reclaim its policy voice. The development of the early childhood Code of Ethics (Dalli \& Mitchell, 1995) was one example of a sector initiative, independent of government, to articulate its professional aspirations at a time when government policy was hostile to these aims. The development of the early childhood curriculum document, Te Whäriki, and the initiation of an innovative assessment a pproach using learning and teaching stories (Carr, May \& Podmore, 1998), were both completed on contract to the Ministry of Education. Nonetheless, the process of their development illustrates collaborative sector action aimed at developing pedagogic documents that would keep faith with the sector's aspirations.

Additionally, and most notably from a policy perspective, the mid-1990s saw a project undertaken by a consortium of representatives from national early childhood organisations and interest groups, brought together, funded and serviced by the New Zealand Educational Institute (NZEI Te Riu Roa). The project aimed to review the state of the early childhood sector and to develop proposals on the policies needed to bring coherence to the sector. Clare Wells, a member of the project secretariat, described the project as "a major, collaborative piece of work which unified the early childhood sector to identify, state and strive toward structural and funding arrangements in support of quality early childhood education" (1998, p. 59). The outcome of this 
collaborative action by the sector was the report Future Directions (Early Childhood Education Project, 1996).

It has become clear in the last few years that this consortium action has been of great significance for recent early childhood policy development. Wells argued that between 1990 and 1995 the early childhood sector had been "locked out of the policy development process" (1999, p. 57) and that Future Directions influenced the Ministry of Education to adopt a more inclusive approach to developing policy for the sector. Even more significantly, Future Directions had a great impact on the 1999 pre-election early childhood education policy statements of the political parties which were to form the coalition government elected that year. For example, prior to the 1999 general elections, Labour's early childhood education policy statement included the objective of developing "a long term strategy for the early childhood sector, in collaboration with the sector" (Labour Party, 1999, p. 2). This objective picked up two of the three broad goals stated in Future Directions (1996, p. 65). The other broad goal in Future Directions was that, "in the long-term", early childhood education services would be "universally funded on a basis that is equitable with the school sector by 2000" (p. 65). Labour's 1999 early childhood education policy document did not make a direct commitment to this third goal of universal funding. It did, however, include the objective "to provide access to high quality affordable early childhood education for all children" (p. 2 ), as well as the principled statement that: "Labour views quality early childhood education as a basic right, which must be available to all children, without regard to wealth, income or where they live" (p. 2).

Clearly, there was consonance between the two documents. The announcement in 2000 that a working group had been convened to make recommendations for a ten-year strategic plan for early childhood education signalled that a convergence had been achieved between the sector's goals for its future development and government's overall policy intentions.

\section{Current Discourse About Children and Children's Rights}

Principled statements about children's rights are relative newcomers to early childhood policy discourse. A discourse of needs has been more the norm. For example, in the prefacing statement of Before Five, David Lange, Minister of Education and Prime Minister of New Zealand, justified the new policies with the statement that children "need a good start in life" (Lange, 1988, p. iii). While this may be seen as simply a rhetorical ploy designed to appeal to adults' generally protective attitude to children, it nonetheless positions children as dependent on the goodwill of adults rather than as citizens with rights, just like adults. By contrast, the Meade Report justified its recommendations on the basis of "respect for the basic rights of children" (Meade, 1988, p. 7). The policy focus on children's needs has been typical also of discourse about children in other fields, such as in literature on child development (Kellmer-Pringle, 1980; Woodhead, 1997). It is only recently that the advocacy focus on children's rights has begun to be more consistently heard. In developmental, research, legal and other literature, this has translated into a focus on listening to the child's voice (Henaghan \& Tapp, 2000; Phillips, 1995; Qvortrup, 1997; Smith, 1996).

In the New Zealand policy context, the discourse of children's rights gained prominence in the mid-nineties through the work of people like Laurie O'Reilly, the late Commissioner for Children, who in 1995 pointed out that the rights of children were easily forgotten in a policy context dominated by "an unrelenting promotion or blitz on the perils of 'welfare dependency' and the promotion of the concept of welfare to wellbeing.... In this environment, the child is often voiceless, the forgotten victim" (O'Reilly, 1995). The discourse of rights also frames the Early Childhood Code of Ethics launched in the same year. The decision to use the language of rights in the Code of Ethics was a deliberate one: It was felt that this would put "the child at the centre" and "give a voice back to the child" (Dalli \& Mitchell, 1995, p. 71), as well as empower "all involved in the early childhood sector, children, parents/whanau/ caregivers, employers and educators" (p. 71). At that time it was felt that the rights of all these participants were at risk within the model of minimal state involvement dominant in the mid-1990s.

Recently, Mitchell (2002a) has pursued the argument that the rights of children should be at the heart of early childhood education policy development. She reviewed a range of documents on how this goal might be upheld and evaluated recent early childhood policies, including the ten year strategic plan, against the recommendations culled from her review. She concluded that a shift towards a "rights based" approach has occurred and that "early childhood education in New Zealand has new political priority" (p. 123). Nonetheless, Mitchell noted also that there remain areas where lack of detail in parts of the strategic plan leave children's rights vulnerable. She observed, for example, that the issue of base funding for the diverse services, and the issue of children's right to free education, remained unresolved in the 
final report of the Strategic Plan Working Group of October 2001. She also argued that work was still needed to ensure the removal of fragmentation in the way that government agencies work with early childhood services.

\section{Early Childhood Policy in 2002: Gains and Challenges}

What then have been the gains from the policy changes of 2002, and what are the remaining challenges?

The policy document, Pathways to the Future: Ngā Huarahi Arataki (Ministry of Education, 2002) was released in September. In the foreword to the document, the Minister of Education, Trevor Mallard, makes a number of principled statements about the value of early childhood education and government's commitment to providing universal access to high quality early childhood services:

The Government's vision is for all New Zealand children to have the opportunity to participate in quality early childhood education, no matter their circumstances ... we must firmly establish early childhood education as the cornerstone of our education system ... we cannot leave to chance the quality and accessibility of early childhood education.... The Government has worked alongside the sector, academics and parents in developing the plan.... As with the development of the plan, successful implementation very much depends on the Government working closely with the early childhood sector. (Ministry of Education, 2002, foreword, our italics)

These principled statements about universal entitlement to early childhood services suggest that the current Government sees its role as fitting within the tradition of a social democratic welfare state model of government where entitlements draw on the universal rights of social citizenship (Esping-Anderson, 2000). In this model, government is positioned in a supportive role with citizens in the provision of care and education services because these services benefit society as well as individuals. The statements in Pathways to the Future about Government working collaboratively with the early childhood sector support this positioning. This is in contrast to a "minimal state" model of government where services are seen as a private good which benefits individuals rather than society (Royal Commission on Social Policy, 1988, p. 214).

In Pathways to the Future (Ministry of Education, 2002a) the principled statements in the Foreword translate into the three core goals of: increasing participation in quality ECE services; improving quality of ECE services; and promoting collaborative relationships (p. 2). Five "shifts in direction" (p. 2) are claimed in the service of achieving these goals, together with seven steps laid out over the ten-year period of the strategic plan. The five shifts in directions are:

- New funding and regulatory systems;

- Better support for community-based ECE services;

- The introduction of professional registration for early childhood teachers;

- Better co-operation and collaboration between ECE services, parent support and development and education, health and social services; and

- Greater involvement by Government in ECE particularly in communities where participation in quality ECE is low. (pp. 2-3)

While Pathways to the Future was only released late in 2002, a number of its supporting policy initiatives were announced, and started to be implemented, soon after the release of the final report of the Strategic Plan Working Group in October, 2001. In the following sections we consider each of the three goals of Pathways to the Future and discuss the relevant policy strategies and directions implemented in 2002.

\section{Increasing Participation in Quality Early Childhood Education}

Increasing participation in quality early childhood education is a complex issue, generating debates about entitlement and free access involving economic arguments as well as ideological positioning. While ideologically the final report of the Strategic Plan Working Group maintains the ideal of free access to early childhood services for all children, both this document and Pathways to the Future were produced with a clear direction from the Minister of Education to turn a "blue skies" vision for early childhood policy into an action plan that took account of Government's "fiscal limits" (Hubbard, 2001). Within a political framework of financial constraints, free access to early childhood services was not mentioned in Pathways to the Future. Free access still remained part of a "blue skies" scenario.

Nonetheless, soon after the release of the final report of the Strategic Plan Working group, a number of strategies started to be announced. 
The "Promoting ECE Participation" Project and Discretionary Grants

Speaking at the Early Years conference organised by the New Zealand Education Institute (NZEI Te Riu Roa) in April 2002, the Minister of Education, Trevor Mallard, highlighted some of government's strategies to increase ECE participation. The Minister noted, especially, the establishment of the Promoting ECE Participation project with a twostage implementation plan over a four-year period. He stated that over $\$ 10$ million had been allocated for this project. Starting in May 2002, the first stage of the project was to focus on examining existing networks of early childhood services, and on identifying where new communitybased ECE services would best be established. The second stage was expected to start in mid-2003 with the goal of identifying communitybased ECE services with low participation rates "and find[ing] ways of providing assistance for them" (Mallard, 2000, April). By the end of 2002 it was clear that this project was well underway - the Ministry of Education advertised its intention to appoint a demographer, a national co-ordinator and seven "network co-ordinators" to advance the policy. The Ministry also announced that it was seeking feedback from the early childhood community on what the project had achieved to date (Ministry of Education, 2002d, p. 2).

At the same NZEI conference the Minister announced supplementary funding of $\$ 5$ million further to the 2002 allocation for the Discretionary Grants Scheme. This scheme was introduced as part of the Before Five policies and over the years had become the primary mechanism through which early childhood centres could receive assistance with the initial capital cost of setting up new centres. The criteria for awarding the grants changed from year to year, and in 2002 the criteria included: providing assistance to centres to increase places in existing centres; providing assistance in planning a project; and providing assistance with establishing Pacific Islands early childhood centres. The grants are disbursed from three pools - a general pool, a Maori pool and a Pacific pool. Over the last decade it has frequently been the case that the number of applicants has exceeded the number that have been able to be funded. The top-up of funds for the 2002 allocation was therefore most welcome and was expected to meet the demand of that year.

\section{The "Design and Build Scheme"}

As an additional way of assisting community-based services with property issues, the Minister also announced an initiative which later was named the "Design and Build Scheme" (Ministry of Education, $2002 c$, p. 4). This scheme aims to reduce the work and cost faced by community-based early childhood providers wishing to set up a new centre. Instead of commissioning their own design and construction, providers are now able to choose a design from a catalogue of options produced by a "preferred building contractor" appointed by the Ministry of Education.

\section{Equity Funding}

Another strategy highlighted by the Minister of Education in his speech to the NZEI Te Riu Roa conference was the new Equity Funding regime which became effective on January 1, 2002, with first payments made on March 1, 2002. Announced in 2001, equity funding is calculated using an equity index (EQI) developed by the Ministry of Education on the basis of the addresses of enrolled children. Equity funding is additional to bulk funding and is intended to: reduce educational disparities between different groups in New Zealand communities; reduce barriers to participation by groups that are under-represented in early childhood services; and support early childhood services to raise children's educational achievement (Ministry of Education, 2001b). Designed to assist not-for-profit community-based ECE services (Mallard, 2002, April, p. 4), this initiative was allocated $\$ 30$ million over a four-year period. The Minister explained:

This money will target funding to licensed and chartered, community-based ECE services in low socio-economic communities. It will also target those based in isolated areas, or ECE services that are based on a language and culture other than English, have a significant numbers of children with special education needs or come from non-English speaking backgrounds. (p. 5)

By November 2002, a ministerial press statement (Mallard, 2002, November, p. 1) noted that 1334 ECE services had benefited from the total of $\$ 8$ million allocated towards Equity Funding in 2002. Services were expected to use the funding towards improving staff:child ratios, transport for children, and professional development for staff. Information on the Ministry of Education website (www.minedu.govt.nz) notes that equity funding is also able to be used towards purchasing curriculum resources, assisting staff to upgrade their qualifications, engaging specialist professionals, subsidising learning experiences outside the service, improving learning spaces, 
promoting the availability of the service within the community and meeting children's nutritional needs. Tenders for evaluating the ways in which the Equity Funding scheme was being used by centres were called for in early 2002, and the first phase of data gathering had been completed by mid-2003.

As a package, these initiatives clearly constitute a substantial increase in government investment in early childhood education and, by and large, have been welcomed by the sector. For example, groups like NZEI Te Riu Roa and Te Tari Puna Ora o Aotearoa, the New Zealand Childcare Association (NZCA), have seen these policies as an indication of "greater government responsibility" for the sector (Rose Cole, NZCA, cited in Gerritsen, 2002), and of Government's commitment to take a "more active role in planning provision for community-based, non-profit, early childhood centres, in areas where children have missed out" (NZEI, 2002). However, a strong voice of dissent has also been heard from private providers within the sector. For example, Ross Penman, president of the Early Childhood Council, has been cited as saying that the Strategic Plan will cause owners of private early childhood centres to walk away from the sector, and that Government was planning to "take over" (Gerritsen, 2002). Perhaps not surprisingly, private providers have also criticised the equity funding policy which automatically rules out privately-owned centres from accessing the funds.

Government's decision to limit access to equity funding to community-based early childhood services is clearly an ideological one related to whether government should be supporting privately-owned centres, run for profit, to the same level as community-owned ones. But a child equity argument against this policy also exists and has been raised by The Child Poverty Action Group (CPAG). This advocacy group comments on a range of matters related to children who live in poverty and it has suggested that targeting the equity funding policy at not-for-profit centres discriminates against children with high needs in private centres. CPAG noted also that equity funding "should not be regarded as a substitute for adequate base funding for all services" (Child Poverty Action Group, 2003, p. 48).

\section{Differences between community-owned and privately-owned centres}

The debate about the extent to which government should support privately-owned centres is not new, and was re-fuelled in 2002 through the publication by the New Zealand Council for Educational Research
(NZCER) of an Occasional Paper (Mitchell, 2002b) on the differences between privatedly-owned and community-owned early childhood centres. Mitchell's paper analysed literature from New Zealand, Canada and the United States on indicators of quality provision, and particularly the qualification levels of early childhood staff employed in different types of early childhood services. Having established that research has demonstrated a connection between "training and qualifications of staff, high rates of staff pay, high staff: child ratios, and small group size" and "good quality education for infants and young children" (p. 2), Mitchell then argued that "private centres are likely to score lower on all these variables" (p. 13). She thus suggested "a model for integrating (private) childcare centres into the state sector" through which stricter quality conditions would be applied to private centres in return for greater government support and funding (p. 13)

While the quality indicators research cited by Mitchell is not new, the suggestion in the report that government should "apply more stringent regulations for teacher qualifications, staff:child ratios, and group size" raised hackles among private providers and a barrage of criticism. Private providers argued that regulations alone, and in particular, the recommendations in Pathways to the Future that 100 percent of teachers be registered by 2012, may have unintended consequences. For example, in a speech to the Early Childhood Council's annual conference, LaRocque argued that regulation, as a route to providing quality is by no means a fool-proof formula. He suggested that an unintended consequence from tighter regulations could be that small private providers would be forced out of the market due to cost "thus reducing the supply of places. Any resulting increase in the price of childcare could put regulated centre-based childcare beyond the reach of many families" (LaRocque, 2003, p. 7). LaRocque also commented that families in this situation "may be forced into the unregulated part of the early childhood sector and may end up using lower-cost and potentially lower quality/less safe forms of care" (p. 7). The concerns he expressed about reduced access to early childhood services for some parts of the community are the same concerns that the policies of Pathways to the Future seek to address. Yet, there is clearly a lack of agreement between the two parts of the early childhood sector, private and community-based, about the route to achieve the same goal. It may be that this lack of agreement will be an ongoing challenge in a sector known for its diversity. 


\section{Improving the Quality of ECE Services}

Ensuring quality in early childhood provision has been a long-standing goal of the New Zealand early childhood sector. In reviewing the state of the ECE sector in the late eighties, the Meade Report listed a set of characteristics known to be associated with high quality ECE provision, and the Before Five policies sought to establish a policy framework that would guarantee these characteristics across the whole range of ECE services. As we noted earlier, these policies did not survive the "New Right" government of the early nineties, and it was largely leadership action from within the sector that enabled its quality agenda to be edged slowly forward through such initiatives as the development of the early childhood curriculum, Te Wharriki; the development of the Early Childhood Code of Ethics; and the development of an assessment approach using learning and teaching stories.

The goal in Pathways to the Future of improving the quality of ECE services, was, therefore, widely welcomed by the sector. In the analysis of submissions made about the consultation document for the development of the Strategic Plan, "high support" was reported (Ministry of Education, 2003c) for all the strategies proposed by the working group to improve quality, with most submissions providing their highest support for changes to ratios and group sizes. Support for legislating for Te Whăriki, for improving teacher qualifications, for making teacher registration compulsory, and for pay parity for early childhood teachers, was also high. Many submissions noted also that improving quality would require additional funding. The array of policies to improve quality, which eventually appeared in Pathways to the Future, reflects the support of the community to the goal of improving quality.

\section{Reviews of funding and regulations}

In a move to tackle two major structural determinants of quality, funding and regulations, a pre-budget statement in 2002 announced that two reviews would be initiated in mid-year to examine these areas. Pathways to the Future justifies this strategy in the following way:

The complexity of the current regulatory and funding regime systems can have negative or unintended impacts on quality and participation. They can also create barriers to participation. A comprehensive review of funding and regulations should benefit families and services as increased government support helps the ECE sector to meet quality and participation objectives" (Ministry of Education, 2002a, p. 6).

The two reviews were launched in July 2002 amid statements assuring, and seeking, community consultation through submissions and public meetings, with the aim that new regulations would be in place by the end of 2004, and a revised funding model operational in 2005.

\section{Best-evidence syntheses: improving planning and support for the} early childhood sector

Within a similar time-period, and in a further initiative to strengthen the infrastructure of early childhood policy, the Ministry of Education called for tenders for six Best-Evidence Syntheses on topics related to: teacher professional development and in-service teacher learning; effective leadership and management in early childhood; the influence of initial teacher education on quality; resources and organisation for quality outcomes; families and communities; and quality teaching. These topics were expected to have immediate application in developing policy to improve quality and a tight three-month turnaround was set for completing the projects. The speed required to complete these syntheses seemed at the time laudable. However, when by the end of 2002 there was still no feedback on the projects completed five months earlier, questions were raised about the capacity of the Ministry of Education to respond to its own work programme.

\section{Increasing the number of qualified early childhood teachers}

In the meantime, a number of other initiatives were also in train, mainly geared towards improving quality via enhanced teacher qualifications. In November 2000, soon after the establishment of the Strategic Plan Working Group, the government had announced changes to the qualifications requirements for "persons responsible" in early childhood centres. The changes meant that by January 1, 2002 all new "persons responsible" at a centre were required to hold a Diploma of Teaching (ECE); all those who were already "persons responsible" had until January 1, 2005 to acquire a Diploma of Teaching (ECE); and by 2012, all people working in centres were to be qualified to this benchmark level.

In order to help centres achieve these goals, Government set in place a number of new policies. These included: Incentive Grants to assist services to meet some of the costs in supporting their staff to undertake training to Diploma level; the introduction of Recognition of Prior Learning (RPL) programmes for practising early childhood teachers 
wanting to upgrade their qualifications to the new benchmark for licensing; TeachNZ scholarships for early childhood teaching, specifically targeted for Maori and Pacific people; and teacher registration.

Incentive grants were advertised in 2001 as a way to help centres which had been affected by the changes to the "persons responsible" requirements. A total of 250 grants were available in 2002, and centres were notified that if more than 250 applications were received, the grants would be allocated to centres with fewer qualified staff (Ministry of Education, 2001a). As it turned out, many more applications were lodged for these grants than anticipated, and the Minister of Education took the opportunity of the launch of Pathways to the Future in September 2002 to announce a further allocation of 90 grants. It was clear that the policy was meeting a real need.

Government's provisions for Recognition of Prior Learning (RPL) programmes were publicised early in 2001, and by July 2001 five providers of early childhood teacher education programmes had been contracted to deliver these programmes in a flexible way to lead to the Diploma of Teaching (ECE). Concurrently with this policy coming on board, Government also announced that all "equivalency" processes had to be completed by December 31, 2001 and that "grandparenting" and licensing points allocations would be discontinued from that date.

Equivalency processes had been instituted in the early 1990s, and enabled non-qualified persons to submit their portfolios of sub-diploma training, and early childhood work experience to the New Zealand Qualifications Authority (NZQA) which would then assess how many licensing points the portfolio merited from the possible maximum of 100 points. The level of 100 points was deemed to be "equivalent" to diploma level training for the purpose of licensing. Equivalency to diploma level is not in itself a qualification, but merely a marker that enough licensing points had been achieved to enable a person to be nominated "person responsible" in an early childhood centre.

Through the discontinuation, by December 31, 2001, of the equivalency processes, enrolment onto the RPL programmes became a necessity for holders of licensing points who wanted to continue working in early childhood education in the long term. The RPL programmes are a way to ensure that all current "persons responsible" without a diploma can gain this by the 2005 deadline; they are also open to any other person holding licensing points who wishes to gain this qualification by 2005 .
Within these initiatives to increase the number of qualified early childhood teachers, a specific focus on recruiting Māori and Pasifika students was made through the allocation of 105 TeachNZ scholarships each year from 2000. In 2002, an additional development promoted by the government was the registration on the NZQA framework of a Pasifika National Diploma of Teaching (ECE). The Pasifika National Diploma was developed through a Ministry of Education decision, and is the only diploma level early childhood teacher education qualification that uses NZQA unit standards. Concern has been expressed by some existing teacher education providers that the use of NZQA unit standards in this qualification might convey a different and inferior status to this qualification, relative to others already in existence. By the end of 2002 it was not clear which providers of early childhood teacher education would deliver this programme.

Clearly these initiatives hold much promise for achieving the goal of increasing the number of qualified early childhood teachers. Positioned alongside the introduction of compulsory teacher registration for all regulated staff in teacher-led early childhood education services by 2012, these initiatives also promise to enhance the sector's professional status, a goal aided by the achievement of pay parity for kindergarten teachers, which began to be phased in on July 1 , 2002.

\section{Pay parity and professional status}

The achievement of pay parity is indeed a landmark event. While pay parity with the primary and secondary sector is currently only available for kindergarten teachers, it is being seen as the harbinger of things to come for the rest of the early childhood sector. Certainly one advantage of pay parity is that it positions the ECE sector on a par with the compulsory parts of the broader education sector. Pay parity also makes it more likely that the Pathways to the Future goal of attracting primary school teachers into early childhood teaching will be achieved. This is clearly an advantage from the point of view of increasing the supply of early childhood teachers.

One other major gain from the achievement of pay parity arises from the terms of the settlement of the Kindergarten Teachers' Collective Agreement. The Minister of Education called this a "principled settlement" because in "setting the rate" for each group of kindergarten staff (teachers, senior teachers and head teachers), the decisions that were made resulted in "establishing the principle of 
alignment of leadership positions across the kindergarten and schools sector" (Mallard, 2002, September). Addressing the "Pay Parity Party"in September, 2002 to celebrate the event, the Minister explained that this alignment was consistent with his view that "the position of kindergarten head teacher, as a professional leader and being responsible for the day-to-day running of the centre, is comparable to that of a principal of a small school". He continued:

I have high expectations of our leaders in education to work on improving quality, lift achievement and build professionalism. Pay parity reflects this expectation, regardless of which part of the education sector a leader is employed in.

The minister's support for pay parity, and for increasing the professionalism of the ECE sector, represents a significant statement of the government's valuing of the contribution that high quality early childhood education makes to society.

Regarded as a package, from the perspective of community-based early childhood services, the government's plans to enhance early childhood teacher qualifications, and to promote professionalism, signal substantial gains for the early childhood sector both in substance as well as in principle. By acting to raise the qualification levels of early childhood teachers, and moving to make early childhood teacher registration compulsory, the government has acknowledged the rights of children to the best that society can offer. At the same time, government has indicated that it now sees itself as having a much more active role in regulating the quality of services for its youngest citizens. Furthermore, by enacting policies to ensure that teachers are recruited from under-represented groups within the teaching population, the government is clearly seeking to address existing inequities in teacher supply.

However, from the perspective of private providers, this change in the role of government has been seen as problematic - in substance as well as in principle. The chair of the Early Childhood Council (ECC), Ross Penman, has been quoted as saying that the "upskilling plan" is "unworkable" and that there were "more teachers leaving the sector than new graduates coming in" (Haines, 2002). Similarly, the chief executive of the ECC, Sue Thorne, was cited in a Listener article (Montgomery, 2002) as predicting that "staff will desert the sector at a time when there is already a dearth of professionals." These comments reveal a very different stance towards Pathways to the Future from the one expressed by predominantly community-based early childhood organisations. The comments also raise questions about the use of terms like "teacher" and "professional" for people employed in early childhood services. If the worry expressed by Penman is about "teachers" leaving the service because they do not wish to upskill to diploma level, then the question needs to be asked if these people can be called "teachers" in the first place. Should they be more accurately referred to as unqualified staff? Similarly, can unqualified staff be called "professionals", given that one of the more-agreed-upon characteristics of a profession is that members share a specialist knowledge base (Katz, 1985). By this definition, a professional service only exists when all staff in early childhood services are trained to a benchmark level.

It would appear that on this issue, as with the previous issue of increasing participation, community-based organisations and those of private providers hold divergent views.

\section{Promoting Collaborative Relationships}

Promoting collaborative relationships is the third goal of Pathways to the Future and is explained in the summary of the document as an intention to "improve the development and educational achievement of children between birth and age eight through forming strong links between ECE services, parent support and development, schools, health and social services" (Ministry of Education, 2002a, p. 3).

\section{Centres of innovation}

The first significant initiative to emerge from Pathways to the Future in support of this goal was the Centres of Innovation (COIs) policy. In November 2002 expressions of interest were invited from early childhood centres to be "set up as a Centre of Innovation for three years" (Ministry of Education, 2002d, p. 6). In applying to be a Centre of Innovation a centre had to be willing to engage in action research and document good practice so that this would be able to be shared through the publication of reports and resources. To facilitate the action research, centres had to nominate researchers with whom they would collaborate to document their effectiveness and make this evidence widely available to a broad early childhood audience. The rationale of this approach was that through the interaction between practitioners and researchers, greater collaboration across the sector would also ensue, focused on good practice. 
Dr Anne Meade, chair of the Strategic Plan Working Group, and long-established researcher, was appointed to oversee the process of selecting the initial set of six Centres of Innovation. The invitation for expressions of interest (Ministry of Education, 2002d) noted that the focus of the selection would be on centres that could demonstrate: quality Māori immersion practices; quality Pasifika immersion or bilingual practices; improved linkages between ECE services, schools, and health and social services; and quality practices in the use of information and communications technology. This focus clearly reflected the key goals of Pathways to the Future, including the use of a "community of learning" approach, and a focus on how information technology is used to "enhance early childhood learning and development."

\section{Collaboration in the transition to school: the need for a "community}

\section{of learning" approach}

The theme of collaboration between early childhood services and schools has received considerable attention in recent years. In 1997 it was the focus of a national seminar organised by the Children's Issues Centre and the Institute for Early Childhood Studies. The plenary sessions of that conference highlighted the differences in the curriculum orientations of the two sectors and confirmed the need for collaborative activity to ensure smoother transitions for children and families from the ECE to the primary school sector.

A recent study in South Auckland, the Early Childhood Primary Link (ECPL) project (for a summary, see Keith et al., 2002) provided evidence that collaborative action by early childhood and primary teachers was able to make a difference in raising the reading and writing achievement levels of the six-year olds who had participated in the study. The project was part of a broader literacy initiative entitled Strengthening Education in Mangere and Otara (SEMO). The report from the project noted that the ECPL project emphasised "building continuity" for children to "deliberately build a common understanding in both early childhood and school settings about issues of transition" (2002, p. 16). The project involved professional development for early childhood and new entrant teachers. For the early childhood teachers, the aims were to "to broaden teachers' ideas about literacy, about teaching, learning, and development, and their goals for children's development" (p.9). For the primary teachers, the aims were to "change teachers' beliefs about language, learning and literacy (that) ... involved teachers helping children make connections between school literacy and children's diverse social worlds and understandings" (p. 10). The study concluded that usual assumptions for the lower scores in literacy as tested by conventional methods for the children in low-decile schools were "neither inevitable nor unbridgeable" (p. 10). It reported that the professional development intervention was able to clarify ways in which early childhood teachers could "enhance children's emergent literacy and language skills and knowledge" (p. 16), and that the success of the intervention depended on knowing the child very well and matching his/her strengths with expectations in early childhood settings, in family settings, in community settings and in school settings. Additionally, the study concluded that "professionals ... can and must form their own effective community of learning" and that teachers must "be prepared to take responsibility for the outcomes of their teaching, not to believe that factors in the home and the child are the cause for lack of progress" (p. 16).

The focus of this study on the collaborative, community of learning approach as a foundation for learning has become a frequent reference point in early childhood discourse about transition. For example, when, in April 2002, NZEI organised its first joint primary and early childhood education conference, Collaborative approaches in the early years, the Minister of Education referred to the ECPL study as an example of "the practical benefits that can be gained from having a dedicated transition program between ECE and school" (Mallard, 2002, April, p. 2). He explained collaboration as "serious teamwork between early childhood services, primary schools, parents, whanau and the community" (p. 1) and urged that all must pull together to "ensure the transition between ECE and school is as seamless - and as painless - as possible" (p. 1).

Beyond collaboration between ECE and school, the third goal of Pathways to the Future includes collaboration with health and social services as highly desirable. This intention to promote "interagency work between the Ministry of Education, Ministry of Health, and Ministry of Social Development to improve links in early years services" (Ministry of Education 2002a, back cover) is in line with other government initiatives, such as the development of the Agenda for Children (Ministry of Social Development, 2002), which was initiated as a response to the 1997 report from the United Nations Committee on the Rights of the Child. Indeed, Agenda for Children and Pathways to the Future share a number of similarities. In Agenda for Children the theme of interagency collaboration is stated as a set of principles for 
government policy consistent with the United Nations Convention of the Rights of the Child and the Treaty of Waitangi. Both documents take a whole child approach and both argue for improved planning, enhanced information flows, and collaborative research to improve the situation of children. Curiously, however, Pathways to the Future does not specifically mention Agenda for Children as a reference point (although the reverse is not true). Is this oversight in Pathways to the Future a mere coincidence, or is it perhaps symptomatic of the real challenges that remain even in the face of policy to the contrary? The outcomes of the Centres of Innovation projects could throw some light on this, as the action research proceeds to document practice within each of the six "communities of learning".

Also of interest will be the definitions that emerge for "community of learning". The notion of community has long been part of early childhood discourse, and "community involvement" is enshrined as desirable in many of the statutory documents that govern early childhood practice (e.g., DOPs; Quality in Action). Parental input and a reliance on voluntary parent help is often interpreted as community support and involvement. However, community involvement is often variable and, as Cohen (1989) has argued, "community" is a slippery concept.

\section{Concluding Comments}

Our focus in this paper has been to review the early childhood policies announced in 2002 as part of the implementation of the ten-year strategic plan for early childhood education, Pathways to the Future. This plan was released in September 2002, and many of the policies within it have yet to bed down. In reviewing these policies we have considered them "from the outside" - neither of us has been directly involved in their drafting. Our involvement in the Strategic Plan process has been as contributors to the community consultation component. This position has enabled us to view the policies as outside observers, gazing in on the policy implementation process as it has unfolded.

In taking our review to the end of 2002, we were mindful that it was still too early to assess fully the likely impact of these policies on the overall shape of the sector. Nonetheless, our review has revealed that 2002 was an impressively active year for policy developers: Within three months of the release of Pathways to the Future, many steps had already been taken towards achieving the intended gains of the strategic plan. The gains have to do with achieving sector goals that have been articulated for many years (Early Childhood Education Project, 1996; Meade, 1988). They have to do with access and participation, adequate funding, ensuring quality of early childhood services and professionalism in the sector, and equity issues for Māori and Pasifika people. They also have to do with children's rights as equal citizens with the rest of society.

Equally our review has revealed that challenges remain. These relate to divergent views about the role of the state in the provision of early childhood education services, and to the difficulty of achieving collaboration across a range of services that hold a brief for children.

The paths have been drawn and the pace has been set. It will be important that the impressive momentum of policy action built up during 2002 is sustained and supported into the next ten years.

\section{References}

Burns, V. (1989). Early childhood in New Zealand: The quiet revolution. Paper presented at the 19th OMEP World Assembly and Congress (available as an ERIC document).

Carr, M., May, H., \& Podmore, V. (1998). Learning and teaching stories: New approaches to assessment and evaluation in relation to Te Whāriki. Wellington: Institute for Early Childhood Studies.

Child Poverty Action Group. (2003). Our children: The priority for policy. (2nd ed.). Auckland: Child Poverty Action Group Inc.

Cohen, A. P. (1989). The symbolic construction of community. London, New York: Routledge.

Dalli, C. (1990). Early childhood education in New Zealand: Current issues and policy developments. Early Child Development and Care, 64, 61-70.

Dalli, C. (1994). Is Cinderella back among the cinders? A review of early childhood education in early 1990s. New Zealand Annual Review of Education, 3, 223-252.

Dalli, C., \& Mitchell, L. (1995, September). The Early Childhood Code of Ethics: Or how you can prise yourself from between a rock and a hard place. Proceedings of the Sixth Early Childhood Convention, Vol. 1, pp. 63-76, Tamaki Makaurau - Auckland.

Dalli, C. (2002, October). Early childhood policy in New Zealand: Stories of sector collaborative action in the 1990s. Paper presented to the Country Seminar for Education International member organisations in the 
OECD countries on Education and Trade Union Policies in New Zealand, Wellington, New Zealand.

Davison, C. (1997). The sinking of the early childhood education flagship? Government's plan to privatise kindergartens: the bulk-funding story. Occasional Paper No. 3. Wellington: Institute for Early Childhood Studies.

Early Childhood Education Project. (1996). Future directions: Early childhood education in New Zealand. Wellington: NZEI Te Riu Roa.

Esping-Anderson, G. (2000). The three worlds of welfare capitalism. Princeton, NJ: Princeton University Press.

Gerritsen, J. (2002). Labour policy to control early childhood education. New Zealand Education Review, 7(26), 1-2.

Haines, L. (2002, September 16). Preschool deadline. Dominion Post.

Henaghan, M., \& Tapp, P. (2000). Judicial and legislative conceptions of childhood and children's voices in family law. In A. B. Smith, M. Gollop, K. Marshall, \& K. Nairn (Eds.), Advocating for Children. International perspectives on children's rights. Dunedin: University of Otago Press.

Hubbard, B. (2001, November). Free EC access remains elusive. New Zealand Education Review, p. 2.

Katz, L. (1985). The nature of professions: Where is early childhood education? Addresss presented at the Early Childhood Organisation Conference in honour of Miss E. Marianne Parry, OBE., Bristol Polytechnic, England, September. Printed in Talks with Teachers of Young Children, pp. 219-235. New Jersey: Ablex Publishing Corp.

Keith, M., Phillips, G., McNaughton, S., \& MacDonald, S. (2002). Picking up the Pac: A summary. Strengthening Education in Mangere and Otara. Auckland: Ministry of Education.

Kellmer-Pringle, M. (1980). The needs of children (2nd ed.). London: Hutchinson.

Labour Party. (1999). Early childhood education policy. Wellington.

Lange, D. (1988). Before Five. Wellington: Government Print.

LaRocque, N. (2003, April). Does economics have anything to say about early childhood education policy? Keynote presentation to the Early Childhood Council Annual Conference, Christchurch.

Mallard, T. (2002, April). Speech Notes. NZEI Early Years Education Conference, Wellington.
Mallard, T. (2000, September). Address at "Pay Parity Party". Wellington College of Education.

Mallard, T. (2002, October). Education and trade union policies. Speech Notes for the Country Seminar for Education International member organisations in the OECD countries on Education and Trade Union Policies in New Zealand, Wellington, New Zealand.

Mallard, T. (2002, November) Funding boost for early childhood education. Minister of Education's press release on equity funding. Ministry of Education. <www.minedu.govt.nz>

May, H. (1991). "From a floor to a drawer". A story of administrative upheaval. A Post-Meade reflection on early childhood policy. Te Timatanga, 9(2), 3-11.

May, H. (2001). Politics in the playground. Wellington. Bridget Williams \& New Zealand Council for Educational Research.

Meade, A. (1988). Education to be more: Report of the early childhood care and education working group. Wellington: Government Print.

Meade, A. (1990, November). Women and young children gain a foot in the door. Women's Studies Journal, 96-110.

Meade, A., \& Dalli, C. (1992). Review of the early childhood sector. New Zealand Annual Review of Education, 1, 113-132.

Meade, A. (2000). The early childhood landscape in New Zealand. In J. Hayden (Ed.), Landscapes in early childhood education: Cross-national perspectives on empowerment - A guide for the new millennium (pp. 83-93). New York: Peter Lang.

Ministry of Education. (1996). Te Whaariki. He Whaariki Matauranga mo nga Mokopuna o Aotearoa: Early childhood curriculum. Wellington: Ministry of Education.

Ministry of Education (2001a). Pitopito Korero, November. Wellington: Ministry of Education.

Ministry of Education. (2001b). Early Childhood Equity Funding. Circular 2001/24. <www.minedu.govt.nz/goto/circulars>

Ministry of Education. (2002a). Pathways to the future: A 10 year strategic plan for early childhood education. Wellington: Ministry of Education.

Ministry of Education (2002b). Pitopito Korero, March. Wellington: Ministry of Education.

Ministry of Education (2002c). Pitopito Korero, July. Wellington: Ministry of Education. 
Ministry of Education (2002d). Pitopito Korero, November. Wellington: Ministry of Education.

Ministry of Education. (2003a). Early childhood education centres of innovation. <www.minedu.govt.nz $>$

Ministry of Education. (2003b). Early childhood education funding and regulatory review update, March. <www.minedu.govt.nz>

Ministry of Education. (2003c). Analysis of submissions received on the consultation document for the development of the strategic plan for early childhood education, August 2001. Last update: March 31, 2003. $<$ www.minedu.govt.nz>

Ministry of Social Development. (2002). New Zealand's agenda for children: Making life better for children. Wellington: Ministry of Social Development.

Mitchell, L. (1996). Crossroads - Early childhood education in the mid1990s. New Zealand Annual Review of Education, 5, 75-92.

Mitchell, L. (2002a). Currents of change: Early childhood education in 2001. New Zealand Annual Review of Education, 11, 123-143.

Mitchell, L. (2002b). Differences between community owned and privately owned early childhood education and care centres: a review of evidence. Occasional Paper 2002, 2 $<$ www.nzcer.org.nz?pdfs/11743.pdf>

Montgomery, D. (2002, April 27). The other teacher crisis. Listener, pp. 28-30.

New Zealand Education Institute (NZEI Te Riu Roa) (2002, April 7). Press release.

Office of the Commissioner for Children. (2002). Briefing paper from Hon Roger McClay Commissioner for Children to Minister of Social Services and Employment. Wellington: Office of the Commissioner for Children.

Office of the Commissioner for Children and the Ministry of Youth Affairs. (2000). Seminar on children's policy: Children's rights discussion paper.

O'Reilly, L. (1995, August). Address to the NZEI Te Riu Roa Annual Meeting, Wellington.

Phillips, D. (1995). Giving voice to young children. European Early Childhood Education Research Journal, 3(2), 5-14.
Qvortrup, J. (1997/1999). A voice for children in statistical and social accounting: A plea for children's right to be heard. In A. James \& A. Prout(Eds.), Constructing and reconstructing childhood (pp. 85-106). London: Falmer Press.

Royal Commission on Social Policy. (1988). Women's Economic Wellbeing. In Future Directions: Report of the Royal Commission on Social Policy, Vol. II, Ch. 3 (pp. 204-235). Wellington: Government Printer.

Smith, A. B. (1994, May). Is quality a subjective or objective matter? Paper presented at the National Seminar: Assessing and improving quality in Early Childhood Centres, School of Medicine, Wellington.

Smith, A., Grima, G., Gaffney, M., Powell,. K., Masse, L., \& Barnett, S. (2000). Strategic research initiative literature review: Early childhood education. Report to the Ministry of Education. Dunedin: Children's Issues Centre.

Wells, C. (1999). Future Directions: Shaping early childhood education policy for the 21st century - A personal perspective. New Zealand Annual Review of Education, 8, 45-60.

Woodhead, M. (1997/1999). Psychology and the cultural construction of children's needs. In A. James \& A. Prout (Eds.), Constructing and reconstructing childhood (pp. 63-84). London: Falmer Press.

\section{The authors}

Dr Carmen Dalli is Director of the Institute for Early Childhood Studies at Victoria University of Wellington and senior lecturer in the School of Education. She has a background in primary and secondary school teaching, but has worked in early childhood education for the past sixteen years. Carmen's research and publications are in the area of the experience of childcare, professionalism and ethical practice in early childhood education, and early childhood policy.

Sarah Te One is a part time lecturer at the Institute for Early Childhood Studies at Victoria University of Wellington. She has a practitioner background as well as experience in professional development. Sarah is currently enrolled as a doctoral student. Her researchinterests include curriculum and assessment, and children's rights. 